\title{
Morphological and molecular investigation of Vexillifera cf. armata Page, 1979 (Amoebozoa: Dactylopodida) isolated from the Pacific Ocean
}

\author{
A.A. Kudryavtsev ${ }^{1,2}$, E.N. Volkova' ${ }^{1}$, F.P. Voytinsky ${ }^{1,3}$ \\ ${ }^{I}$ Laboratory of Cellular and Molecular Protistology, Zoological Institute of the Russian Academy \\ of Sciences, Universitetskaya nab. 1, 199034 St. Petersburg, Russia. \\ E-mail: alexander.kudryavtsev@zin.ru, arcellinidae@gmail.com \\ ${ }^{2}$ Department of Invertebrate Zoology, Faculty of Biology, St. Petersburg State University, \\ Universitetskaya nab. 7/9, 199034 St. Petersburg, Russia. \\ ${ }^{3}$ Department of Zoology, A.I. Herzen State Pedagogical University of Russia, Nab. Moyki 48, \\ 191186 St. Petersburg, Russia. E-mail: veles-2015@yandex.ru
}

ABSTRACT: A strain of Vexillifera Schaeffer, 1926 was isolated from the bottom sediments of the Vostok Bay of the Sea of Japan and showed close similarity to $V$. armata Page, 1979. The new strain shares several morphological characters of this morphospecies, in particular, cell coat structure and the presence of unique "trichocyst-like bodies" in the cytoplasm. The studied strain branches in one of the clades of marine Vexillifera species, with the unnamed Mediterranean Vexillifera strain K9 as its closest relative. Unfortunately, the type strain of $V$. armata was lost before any molecular data were obtained. Therefore, no information is available on this species for molecular comparison. The studied strain was isolated from the habitat geographically very distant from the type one. The type strain of $V$. armata was estuarine, while the new strain was isolated from the lower sublittoral benthos and appears to be stenohaline based on the results of an experimental study. It also showed some elusive morphological differences that may be regarded as intraspecific variation. Although currently known extent of cryptic speciation in the naked lobose amoebae is relatively high, the differences between the studied strain and $V$. armata may be too subtle to warrant a description of a separate species. Therefore, we conclude that the new strain should be identified as Vexillifera cf. armata. Re-isolation of $V$. armata from its type locality is highly desirable to evaluate a degree of molecular variability within this morphospecies.

How to cite this article: Kudryavtsev A.A., Volkova E.N., Voytinsky F.P.. 2020. Morphological and molecular investigation of Vexillifera cf. armata Page, 1979 (Amoebozoa: Dactylopodida) isolated from the Pacific Ocean // Invert. Zool. Vol.17. No.4. P.385-402, video. doi: 10.15298/invertzool.17.4.04

KEY WORDS: Amoebozoa, cryptic species, Dactylopodida, molecular phylogeny, morphology, Vexillifera. 


\title{
Морфологическое и молекулярное исследование амебы Vexillifera cf. armata Page, 1979 (Amoebozoa: Dactylopodida), изолированной из Тихого океана
}

\author{
А.А. Кудрявцев ${ }^{1,2}$, Е.Н. Волкова', Ф.П. Войтинский ${ }^{1,3}$ \\ I Лаборатория клеточной и молекулярной протистологии, Зоологический институт РАН, \\ Университетская наб. 1, 199034 Санкт-Петербург, Россия. \\ E-mail: alexander.kudryavtsev@zin.ru, arcellinidae@gmail.com \\ ${ }^{2}$ Кафедра зоологии беспозвоночных, Биологический факультет, Санкт-Петербургский \\ государственный университет, Университетская наб. 7/9, 199034 Санкт-Петербург, Рос- \\ сия. \\ ${ }^{3}$ Кафедра зоологии, Российский государственный педагогический университет им. А.И. \\ Гериена, Наб. Р. Мойки 48, 191186 Санкт-Петербург, Россия. E-mail: veles-2015@yandex.ru
}

РЕЗЮМЕ: Штамм амеб, идентифицированных как представители рода Vexillifera Schaeffer, 1926, был изолирован из донного грунта залива Восток Японского моря. Исследованные амебы были сходны с видом $V$. armata Page, 1979. Изученный штамм обладает несколькими морологическими признаками этого вида, в частности, похожим строением покрова клетки и уникальными «трихоцистоподобными структурами» в цитоплазме. Изученный штамм на филогенетическом древе входит в состав одной из ветвей, объединяющих морских представителей рода Vexillifera; его ближайшим родственником является неидентифицированный штамм К9 из Средиземного моря. К сожалению, типовой штамм $V$. armata был утрачен до того, как появилась возможность провести какие-либо молекулярные исследования этих амеб. Поэтому сравнить обнаруженный нами штамм и $V$. armata на основании молекулярных последовательностей невозможно. Изученный в данной работе штамм изолирован из биотопа, географически очень удаленного от того, где был найден штамм Пэйджа. Типовой штамм $V$. armata выделен из эстуария, в то время как штамм, изученный в данной работе, обнаружен в бентосе нижней сублиторали и по результатам проведенных экспериментальных исследований, возможно, является стеногалинным. Этот штамм также обладает очень незначительными морфологическими отличиями от типового штамма V. armata, которые можно трактовать как внутривидовые. Хотя в настоящее время среди голых лобозных амеб известны случаи видовдвойников, различия между изученным штаммом и типовым штаммом $V$. armata, вероятно, слишком незначительны для описания отдельного вида. Поэтому мы делаем вывод о том, что изученный штамм следует обозначить как Vexillifera $\mathrm{cf}$. armata. Для оценки уровня варьировани молекулярных маркеров в пределах морфологического вида Vexillifera armata крайне желательна реизоляция амеб, относящихся к этому виду, из типового местообитания.

Как цитировать эту статью: Kudryavtsev A.A., Volkova E.N., Voytinsky F.P.. 2020. Morphological and molecular investigation of Vexillifera $\mathrm{cf}$. armata Page, 1979 (Amoebozoa, Dactylopodida) isolated from the Pacific Ocean // Invert. Zool. Vol.17. No.4. P.385-402, video. doi: 10.15298/invertzool.17.4.04

КЛЮЧЕВЫЕ СЛОВА: Amoebozoa, виды-двойники, Dactylopodida, молекулярная филогения, морфология, Vexillifera. 


\section{Introduction}

The genus Vexillifera Schaeffer, 1926 (Amoebozoa: Dactylopodida) comprises 25 named species with morphological and molecular details described to a very different degree (Penard, 1890, 1902; Schaeffer, 1926; Wailes, 1932; Page, 1969, 1972, 1979a, b; Sawyer, 1975; Bovee, 1985; Dyková et al., 2011; Van Wichelen et al., 2016; Kudryavtsev et al., 2018). The genus is very heterogeneous morphologically, yet all its members form a single clade on the molecular phylogenetic tree of Amoebozoa based on the small subunit (SSU) rRNA gene (Dyková et al., 2011; Van Wichelen et al., 2016; Kudryavtsev et al., 2018). In addition, they are characterized by specific sequence motifs in this marker, in particular, a very divergent, unusually short and AT-rich part of the hypervariable region V4 corresponding to the helices 23/e1 and 23/e2 (Kudryavtsev et al., 2018). The clade of Vexillifera spp. branches at the base of the Dactylopodida (Smirnov et al., 2005; Dyková et al., 2011; Kudryavtsev, Pawlowski, 2015; Van Wichelen et al., 2016; Kudryavtsev et al., 2018) and is one of the most stable and longest branches among the Discosea due to a significant divergence of its sequences from the rest of this clade. Regardless of the robustness of this clade, its morphological and ecological heterogeneity may prompt for description of several genera, once more species are investigated using ultrastructural and molecular methods. Only a small fraction of named species of Vexillifera has been simultaneously studied using microscopic and molecular methods (Kudryavtsev et al., 2018). Several species of the genus Vexillifera have previously been studied using microscopic methods only (e.g. Bovee, 1985; Bovee, Sawyer, 1979; Page, $1979 b)$, but it is based on these data that the current concept of the genus Vexillifera has partly been elaborated (Kudryavtsev et al., 2018). Therefore, molecular phylogenetic data have to be collected for these species to incorporate them in the current scheme of the phylogeny of the genus. As it is often the case among the naked lobose amoebae, this task may be challenging when no reference cultures of these previously described species are preserved from these studies (Smirnov, Brown, 2004).

Vexillifera armata Page, 1979 is the species with neither phylogenetic data nor type culture available. This amoeba was isolated by Page (1979a) from the Frogmore Creek off the Kingsbridge estuary (South Devon, England, UK) and investigated using light and electron microscopy. This is the only species of Vexillifera where the enigmatic trichocyst-like bodies in the cytoplasm were described, and one of the two with the glycocalyx composed of hexagonal glycostyles. The culture was deposited with the Culture Collection of Algae and Protozoa (CCAP) in UK, but subsequently lost before any molecular data could be obtained. Later, a strain identified as $V$. armata was isolated by T. Nerad in 2000 from the salt marsh on the USA east coast and deposited in American Type Culture Collection as strain ATCC $\AA 50883^{\mathrm{TM}}$. Only SSU-rRNA gene sequence was obtained for this strain (Peglar et al., 2003), but as it quickly became clear (Mullen et al., 2005), this sequence is almost identical to the one of Pseudoparamoeba pagei (Sawyer, 1975). The genuine members of Vexillifera always form a clade distinct from Pseudoparamoeba (Dyková et al., 2011; Kudryavtsev et al., 2018). Later on, a strain of Vexillifera was isolated and studied from the marine habitat in the Mediterranean Sea, that resembled $V$. armata possessing similar trichocyst-like bodies, but had a different cell coat (Pizzetti et al., 2016). The purpose of this paper is to report an isolation and a molecular investigation of another strain of Vexillifera that is morphologically almost identical to $V$. armata Page, 1979.

\section{Materials and Methods}

\section{Sampling, isolation and cultivation}

A strain of amoeba designated VO16.21.I.5.1 was isolated from the sample of the upper layer $(1 \mathrm{~cm})$ of bottom sediments collected in Vostok Bay of the Sea of Japan $\left(42.69579^{\circ} \mathrm{N}, 132\right.$. $58841^{\circ} \mathrm{E}$ ) at the depth of $70 \mathrm{~m}$ on September, $13^{\text {th }} 2016$. The seawater salinity at the time of 
sampling was $34 \%$. Samples were collected using a modified Van Veen grab, and subsampling of the sediment performed immediately using a sterile plastic spoon into sterile $100-\mathrm{ml}$ plastic container. Ca. $0.5 \mathrm{ml}$ portions of sediment were aseptically inoculated into $90-\mathrm{mm}$ plastic Petri dishes filled with filter-sterilized $(0.22 \mu \mathrm{m})$ seawater with addition of three autoclaved wheat grains per dish. Amoebae were detected in inoculated samples using a Leica DM IL inverted microscope. The culture was purified and cloned by transferring single cells with a glass capillary pipette into the plastic Petri dishes filled with artificial medium obtained by dissolving sea salt (Red Sea Coral Pro) in double-distilled water to a concentration of $30 \%$ with addition of two sterile wheat grains per 60-mm Petri dish. Bacteria co-isolated with amoebae from the sample served as the food source. The clonal cultures were maintained in $60-\mathrm{mm}$ plastic Petri dishes for investigations and in 50-ml tissue culture flasks with aerated caps (TPP) for long-term storage. Light microscopic investigations were performed as described in Kudryavtsev et al. (2019).

For transmission electron microscopic studies amoebae were fixed using $2.5 \%(\mathrm{v} / \mathrm{v})$ solution of glutaraldehyde in $0.05 \mathrm{M} \mathrm{Na}$ cacodylate buffer ( $\mathrm{pH}$ 7.4) prepared with $30 \%$ salinity medium for $40 \mathrm{~min}$ followed by a $1 \%(\mathrm{w} / \mathrm{v})$ solution of osmium tetroxide in the same buffer mixture for one hour. All other details of fixation and further sample processing protocol were done as in Kudryavtsev et al. (2019). Ultrathin sections were observed using a JEOL Jem-1400 transmission electron microscope operated at $80 \mathrm{kV}$.

\section{Salinity tolerance experiments}

To test for survival and growth, small amounts of amoebae taken from the cultures in their growth phase were inoculated into the media with different salinities in three repetitions. Cells in a culture flask containing $15 \mathrm{ml}$ of the medium were suspended by vigorous shaking, and a small portion of suspension (approximately two $\mathrm{ml}$ ) was put into $50-\mathrm{ml}$ plastic centrifuge tubes filled with seawater of required salinity. After mixing thoroughly by inversion, the resulting suspension was distributed equally between three $60 \mathrm{~mm}$ Petri dishes. This method was used with all the salinities in this experiment. The experimental salinity values tested were: $0.5,5,10,15,30,40,50,70$, and $90 \%$. The inoculated dishes were checked in approximately 30 minutes after inoculation to make sure enough amoebae were inoculated into the dish. Control cultures inoculated in a similar way into the original salinity $(30 \%)$ were included in every experiment. Petri dishes were sealed with Parafilm, and condition of amoebae was checked with the inverted microscope in two hours after inoculation, followed by regular observations during subsequent 2-3 weeks.

\section{Molecular phylogenetic analyses}

The total DNA was isolated from densely growing cultures using the guanidine isothiocyanate method of Maniatis et al. (1982). PCR amplification of the SSU rRNA gene was performed using a primer pair A10s1 and RibB (Medlin et al., 1988; Kudryavtsev et al., 2009) with annealing temperature $+50{ }^{\circ} \mathrm{C}$. The amplicons obtained from two independently isolated DNA samples were purified using spin columns of the CleanUp Standard PCR purification kit (Evrogen) and sequenced directly using terminal and universal internal primers for the SSU rRNA gene. A 715-bp barcoding fragment of the cytochrome $\mathrm{C}$ oxidase subunit 1 (COI) gene was amplified as described in Nassonova et al. (2010). The amplicon was purified as indicated above, and sequenced directly using PCR primers. The initial steps of the phylogenetic analyses were performed as described in Kudryavtsev et al. (2019). The final alignments consisted of 81 SSU rRNA gene sequences of 'Flabellinia' (i.e. Vannellida and Dactylopodida) including all currently available sequences of Vexillifera spp. and several sequences of uncultured lobose amoebae known from the previous studies (Berney et al., 2004; Poitelon et al., 2009) that showed a tendency to group with Vexillifera in preliminary analyses. A total of 1516 bps unambiguously aligned sites were analysed. RAxML v. 8.2.12 (Stamatakis, 2014) 
was used for the maximum likelihood (ML) tree inference with GTRGAMMAI substitution model and bootstrap with 1000 pseudoreplicates. Bayesian analysis was performed using MrBayes 3.2.6 (Ronquist et al., 2012) with GTR substitution model, Covarion model and a Gamma distribution model for the site rate variation, with eight rate categories and a proportion of invariable sites. Markov chain Monte Carlo analysis was run for 10000000 generations with a burn in fraction of 0.25 samples. Two runs of four simultaneous chains finally converged with the average standard deviation of the split frequencies of 0.002548 . Chain results were analysed using Tracer v. 1.6 (Rambaut et al., 2014) to ensure sufficient sampling of the parameters. The second SSU rRNA gene alignment (1450 unambiguously aligned positions) analysed using the same parameters consisted of all available sequences of the genus Vexillifera with three sequences of Cunea spp. as outgroup. COI gene alignment included 48 nucleotide sequences (all currently available species of Dactylopodida and Vannellida as an outgroup, with 606 nucleotide positions. Tree reconstruction was performed similarly to the SSU rRNA gene analysis, but the Bayesian inference used 20000000 generations and the chains converged to the average standard deviation of the split frequencies of 0.001252 .

\section{Results}

Morphology of the strain VO16.21I.5.1

During locomotion amoebae of this strain were $14.8-32.0 \mu \mathrm{m}$ long by $7.4-19.3 \mu \mathrm{m}$ broad (average 20.5 by $12.1 \mu \mathrm{m}$ ), with length: breadth ratio 0.9:1-2.9:1 (average 1.8:1). The locomotive forms were flattened, usually the anterior part of the cells was the broadest, and amoebae were tapering towards the pointed uroid (Fig. 1A, D). Sometimes cells were ovoid and equally broad in the anterior and posterior parts, with smooth, rounded uroid (Fig. 1C). The cytoplasm consisted of a flattened anterior hyaline area that occupied up to a half of the cell, and the granuloplasm located posteriorly. The anterior margin of the hyaloplasm was uneven, with short, blunt subpseudopodia. Amoebae also produced longer subpseudopodia that were formed on the dorsal surface of the cell (Fig. 1D, E). Their maximal length equaled approximately half of the length of the cell. Some of these subpeudopodia were thickened at their tips and had a clavate appearance. These subpseudopodia were usually directed anteriorly and actively waved in the medium while the cell was moving forward (Supplementary Video S1). After relocation towards the posterior end of the cell, they bent at their bases and started to point towards a posterior direction (Fig. 1D, F) that was usually followed by their fast withdrawal. The uroid sometimes carried the remnants of these subpseudopodia (Fig. 1A), but no other differentiated uriodal structures were produced. Some of the cells temporarily expanded during locomotion in the direction of movement by adhesion of their posterior end to the substratum (Fig. 1F). Locomotion on the glass surface was usually unstable, with frequent stops and changes in the direction of movement. When changing the direction, the cells expanded their anterior hyaline area in the new direction of movement (Fig. $1 \mathrm{G})$. The average locomotive rate at $+22 \ldots$ $+25{ }^{\circ} \mathrm{C}$ was $25.7 \mu \mathrm{m} \mathrm{min}^{-1}\left(18.0-35.4 \mu \mathrm{m} \mathrm{min}^{-1}\right.$; $\mathrm{n}=7$ ) that comprised about one cell length per minute. Floating forms were frequently produced in cultures. They had an irregular shape with the cytoplasm contracted in the form of irregularly spherical or ovoid mass producing two to six slender, hyaline pseudopodia that could be up to three times as long as the diameter of the central cytoplasmic mass (Fig. 2). The nucleus was spherical, of vesicular type, with the large, central nucleolus (Fig. 1E, F). The diameter of nucleus and nucleolus was 3.3-5.7 $\mu \mathrm{m}$ (average $4.3 \mu \mathrm{m}$ ) and 1.8-3.1 $\mu \mathrm{m}$ (average $2.6 \mu \mathrm{m}), \mathrm{n}=29$, respectively. During locomotion the nucleus was usually located either in the central part of the granuloplasm or in its anterior part, close to the border between hyaloplasm and granuloplasm. The granuloplasm contained numerous food vacuoles enclosing bacteria (Fig. $1 \mathrm{~F})$ and several prominent large vacuoles that contained the remnants of digested material and appeared to be the derivatives of the food vac- 

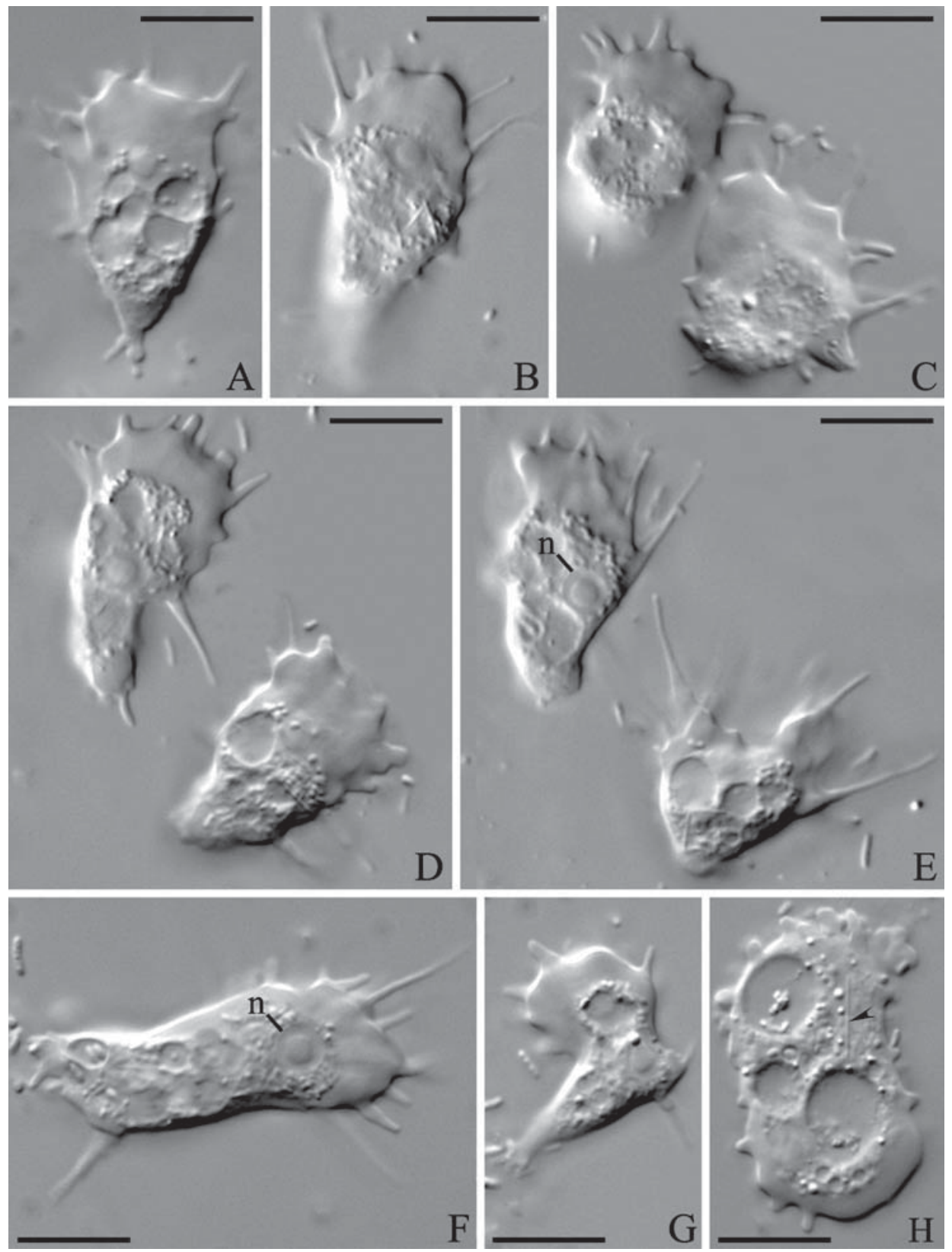

Fig. 1. Light microscopic micrographs of Vexillifera $\mathrm{cf}$. armata strain VO16.21I.5.1 in vivo (DIC). A-F locomotive forms; $\mathrm{G}$ - non-directly moving amoeba; $\mathrm{H}$ - amoeba squeezed by the coverslip showing a trichocyst-like body (arrowhead). D-E - amoebae photographed in two different focal planes to show dorsal subpseudopodia (in E). Abbreviations: $\mathrm{n}$ - nucleus. Scale bar: $10 \mu \mathrm{m}$.

Рис. 1. Прижизненные светооптические микрофотографии Vexillifera cf. armata штамм VO16.21I.5.1 (дифференциальный интерференционный контраст). A-F — локомоторные формы; $\mathrm{G}$ - ненаправленно перемещающаяся амеба; $\mathrm{H}$ - амеба, придавленная покровным стеклом, видна трихоцистоподобная структура (стрелка). D-E - амебы, сфотографированные в двух разных оптических плоскостях для демонстрации дорзальных субпсевдоподий (на Е). Обозначения: $\mathrm{n}$ - ядро. Масштабная черта: 10 мкм. 


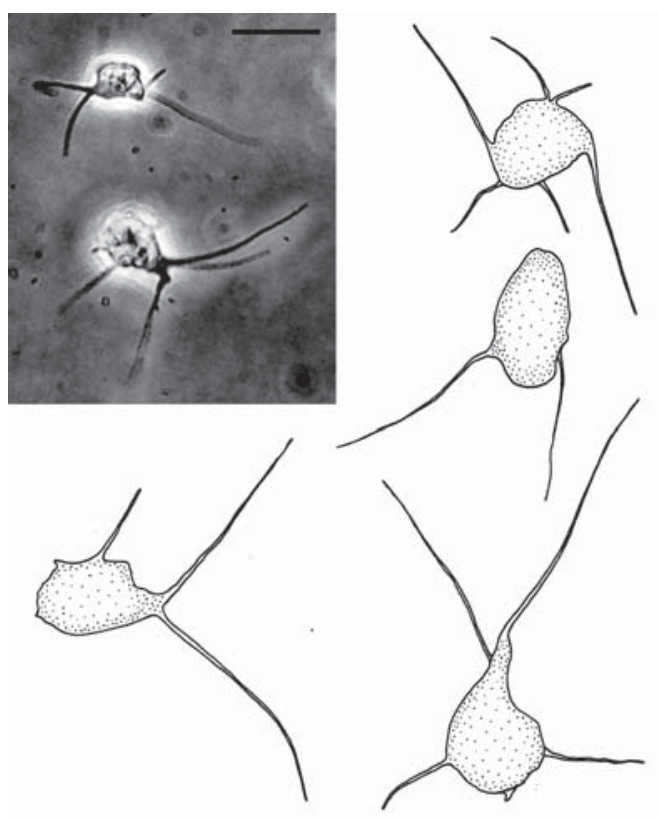

Fig. 2. Light microscopic micrograph (upper left) and schematic drawings of the floating forms of Vexillifera cf. armata strain VO16.21I.5.1. Scale bar: $20 \mu \mathrm{m}$.

Рис. 2. Светооптическая микрофотография (левый верхний угол) и схематические изображения флотирующих форм Vexillifera $\mathrm{cf}$. armata штамм VO16.21I.5.1. Масштабная черта: 20 мкм.

uoles (Fig. 1H). The granuloplasm in all amoebae observed with light microscopy also contained about five rod-shaped structures without a permanent position in the cell, best seen when an amoeba was slightly squeezed with a coverslip (Fig. 1H). The length of these structures measured on slides was 3.3-7.2 $\mu \mathrm{m}$ (average $4.9 \mu \mathrm{m}), \mathrm{n}=11$.

Transmission electron microscopy demonstrated a plasma membrane uniformly covered with the glycocalyx consisting of the prismatic glycostyles (Fig. 3A, B). The glycostyles appeared to be attached to the plasma membrane with plate-like bases, and consisted of six stalks raising over the base plate and forming a characteristic hexagonal structure in tangential sections. The stalks appeared to be interconnected with each other at the top of a glycostyle. The cytoplasm contained electron-dense structures adjacent to the plasma membrane that were rounded or ovoid, 56-132 $\mathrm{nm}$ across (average $81.9 \mathrm{~nm}$ ), n=45 (Fig. 3A, B, D). These structures appeared to be unevenly distributed across the surface, and were most numerous in the parts of the sections that corresponded to the peripheral areas of the cell. The nucleus in sections was irregularly rounded, with the central, electron-dense nucleolus (Fig. 3C). Subpseudopodia, when present in the sections, contained longitudinal bundles of microfilamentous material (Fig. 3D). Mitochondria in sections were spherical or ovoid, with tubular cristae (Fig. $3 \mathrm{E})$. The Golgi dictyosome was about $2 \mu \mathrm{m}$ across and consisted of five or six stacked cisternae (Fig. 3F). Numerous cytoplasmic microtubules were seen adjacent to the dictyosome in favorable sections (Fig. 3G). The rodshaped structures were regularly seen in the granuloplasm and had a quadrangular (approximately square) shape in cross-section (Fig. $3 \mathrm{H}$ ). Average length of the sides of this quadrangular structure was $98.75-152.00 \mathrm{~nm}, \mathrm{n}=8$. The core of these structures was finely granular, and surrounded by several layers of membranous material. These structures appeared to be surrounded by the outermost membrane that looked similar to the membrane of rough endoplasmic reticulum, especially in the longitudinal sections (Fig. 3I).

\section{Molecular phylogenetic relationships}

Amplified and sequenced portion of the SSU rRNA of the studied strain was $1809 \mathrm{bp}$ long for both fragments independently obtained from two DNA samples. There were no internal indels in these sequences, and they were almost identical, except for three nucleotide positions close to the 3' end. The $\mathrm{G}+\mathrm{C}$ content of the sequences was $31.6 \%$. Three molecular clones of partial cytochrome $\mathrm{C}$ oxidase subunit 1 (COI) gene amplicon were 666 base pairs long excluding primers that corresponded to 221 amino acid residues (the first nucleotide after forward primer corresponded to the third codon position, therefore the full coding sequence obtained effectively consisted of 663 nucleotides). Sequences of the mo- 

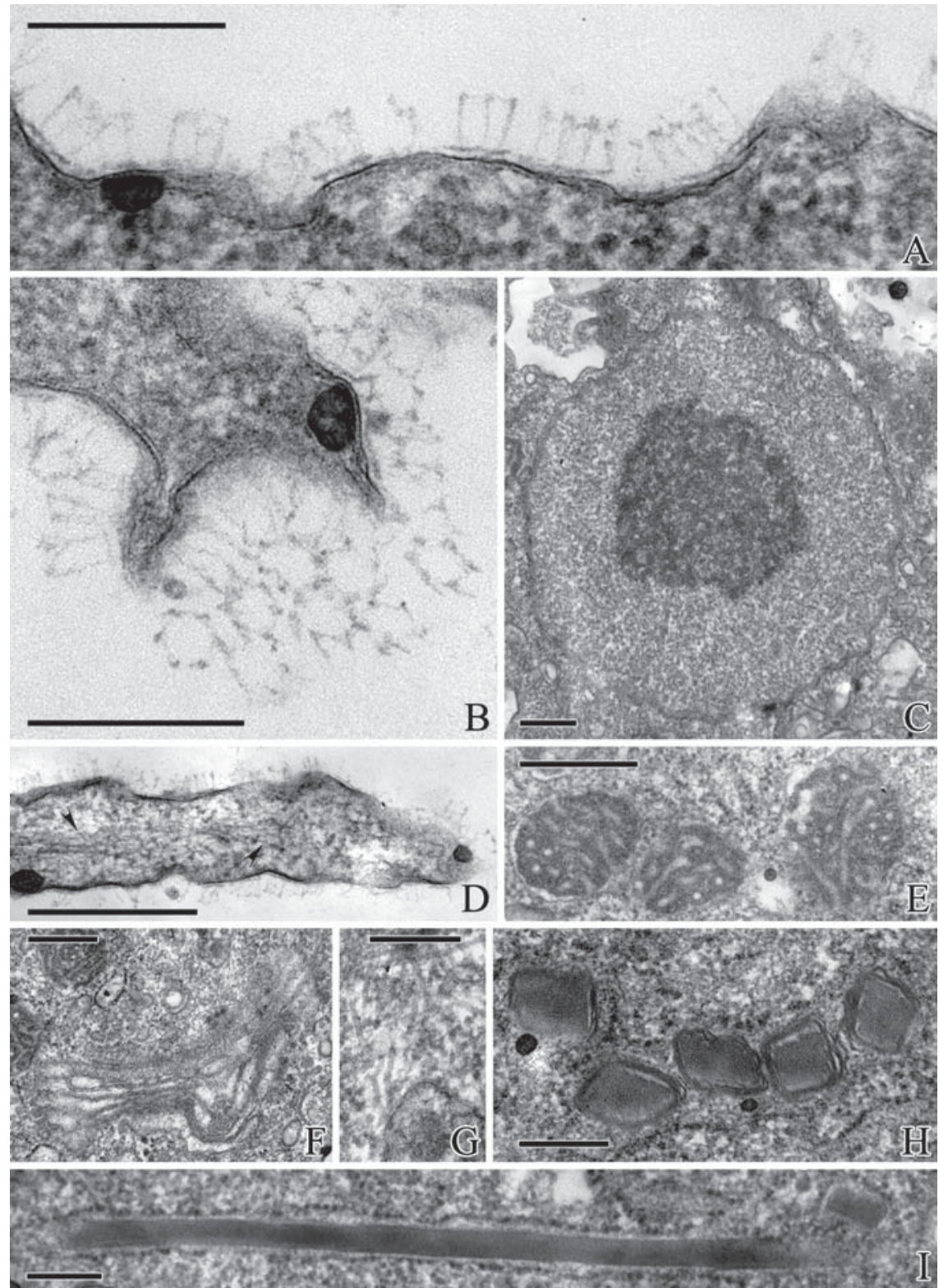

Fig. 3. Transmission electron micrographs Vexillifera $\mathrm{cf}$. armata strain VO16.21I.5.1. A - vertical section of the plasma membrane and glycocalyx; B - tangential section of the glycocalyx; C - nucleus; D subpseudopodium containing axial bundle of microfilaments (arrowheads); E - mitochondria; F — Golgi dictyosome; $\mathrm{G}$ - cytoplasmic microtubules near the dictyosome; H - "trichocyst-like bodies" in a crosssection; I - "trichocyst-like body" in a longitudinal section. Scale bars: A, B, G-I $-0.2 \mu \mathrm{m}$; C-F $-0.5 \mu \mathrm{m}$. Рис. 3. Трансмиссионная электронная микроскопия: Vexillifera $\mathrm{cf}$. armata, штамм VO16.21I.5.1. А вертикальный срез плазматической мембраны и гликокаликса; В — гликокаликс на тангентальном срезе; C - ядро; D - продольный срез субпсевдоподии с аксиальным пучком микрофиламентов (показан стрелками); E - митохондрии; F — диктиосома аппарата Гольджи; $\mathrm{G}$ - цитоплазматические микротрубочки рядом с диктиосомой; Н — "трихоцистоподобные структуры” на поперечном срезе; I - "трихоцистоподобная структура" на продольном срезе. Масштабная черта: A, B, G-I 0,2 мкм; C-F - 0,5 мкм. 
lecular clones of the COI gene amplicon differed from each other in $0.5-1.1 \%$ of the nucleotide positions (up to eight variable nucleotides) that corresponded to $1-2.3 \%$ differences between the amino acid positions (five variable positions) showing that most of the detected nucleotide substitutions were nonsynonymous within the genome. The $\mathrm{G}+\mathrm{C}$ content in the COI gene was $27.37 \%$ and $27.52 \%$ depending on the molecular clone. Differences between the studied strain and other species of Vexillifera in the COI gene sequences were in $9.6-17.8 \%$ of the 417 nucleotide position (average 14.17\%; $\mathrm{n}=30$ ); $V$. bacillipedes was the most distant (17.1-17.8\%), while Vexillifera sp. strain MX6 isolated from AGD-infected Atlantic salmon (English et al., 2019) was the closest one (9.6-10.8\%).

Phylogenetic analysis based on the SSU rRNA gene robustly placed the strain VO16.21I5.1 in the clade corresponding to the order Dactylopodida, in particular, within the genus Vexillifera. This clade contained several stable branches that are unified by their origin. In particular, a derived "freshwater" branch contained all freshwater species of Vexillifera including those isolated from freshwater hosts and, surprisingly, four sequences of uncultured amoebozoans from freshwater biotopes (Fig. 4). Two clades branching at the base of Vexillifera spp. comprised exclusively marine and brackish water species. The studied strain was in a clade comprising $V$. tasmaniana, $V$. abyssalis and two unnamed strains S2M1 and K9; the former isolated from the turbot (Scophthalmus maximus), while the latter, from the marine lagoon at the eastern Italian coast (Dyková, Kostka, 2013; Pizzetti et al., 2016). The latter strain was the closest relative to VO16.21I5.1 (support 1.0/100). It is noteworthy that the clade topology for Vexillifera spp. is not stable against the algorithm of analysis. In particular, two clades comprising marine species swapped their positions in the maximum likelihood and Bayesian trees (Fig. 4), however, both positions had a maximal support. When the phylogenetic tree was reconstructed on the basis of the $18 \mathrm{~S}$ rRNA gene dataset comprising only all sequences of
Vexillifera with Cunea spp. as outgroup, the branching order of the basal clades was stable against the algorithm of analysis (Fig. 5). The clade comprising $V$. tasmaniana, $V$. abyssalis, unnamed strains K9 and S2M1, and the strain VO16.21I5.1 was the most basal in both, ML and Bayesian analysis.

The phylogenetic trees based on the COI gene sequences had topologies that differed from those yielded in maximum likelihood analysis, however, the clades corresponding to Vannellida and Dactylopodida were always monophyletic. In the Dactylopodida clade Cunea spp. was the most basal branch, and Vexillifera spp. grouped between Cunea spp. and the rest of the clade (Fig. 6). Three molecular clones sequenced for the studied strain grouped with the other marine species, in particular, V. abyssalis and Vexillifera sp. MX6. Vexillifera minutissima and $V$. kereti formed separate branches, and $V$. bacillipedes intermingled between them, but this position was not supported. An application of the codon model in the tree reconstruction based on the COI gene yielded even more different topology compared to the SSU rRNA gene, in particular, the genus Vexillifera was not monophyletic, as $V$. bacillipedes branched separately from other members of the genus. However, the studied strain grouped in the same clade and with the same topology as in the COI gene tree based on the GTR model (not shown).

\section{Salinity tolerance of the strain VO16.21I5.1}

Experiments on the strain VO16.21I5.1, show that this species so far demonstrates very narrow salinity tolerance range, as amoebae die or significantly slow down their growth in every tested salinity level above 40 and below 20\%. Amoebae showed no survival and no growth in the salinities of 0.5 and 5\%. In 10\%o amoeba showed some growth initially, but after a short time the growth stopped, and cells did not survive. The cultures started showing faster growth in $15 \%$, and reached their peak in 30 and $40 \%$ slowing down again in 50\%, and showing almost no growth in 70 and $90 \%$. 


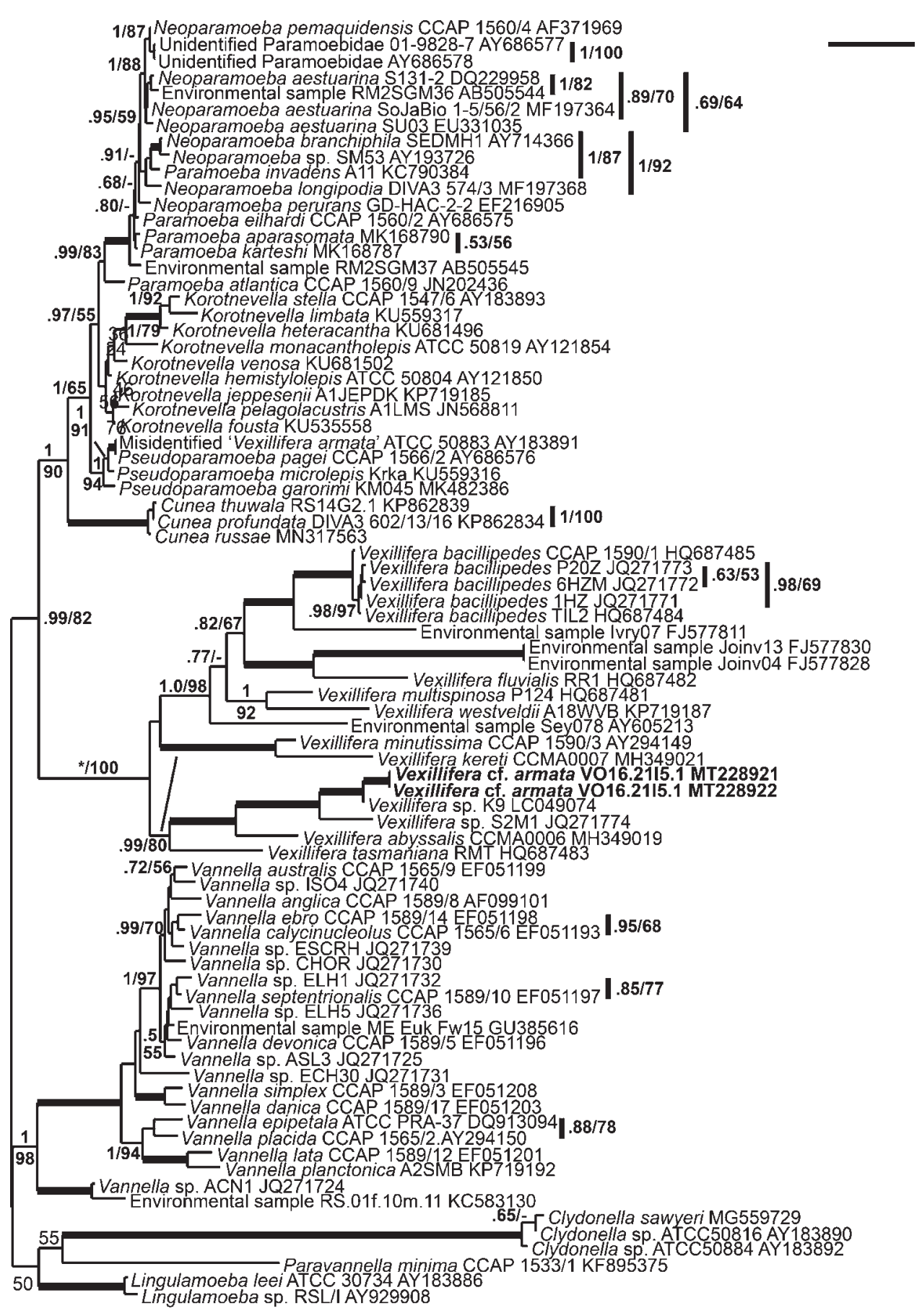

Fig. 4. Maximum likelihood phylogenetic tree of Dactylopodida with selected species of Vannellida as outgroup. The tree is based on 81 SSU rRNA gene sequences (1516 unambiguously aligned nucleotide positions). New sequences of Vexillifera cf. armata are in bold. Numbers at nodes indicate Bayesian posterior probabilities/bootstrap values if above $0.5 / 50$. Thick lines $=1.0 / 100$. The line between two clades of Vexillifera indicates that they are swapped in the Bayesian tree. Scale bar -0.1 substitutions/site. 


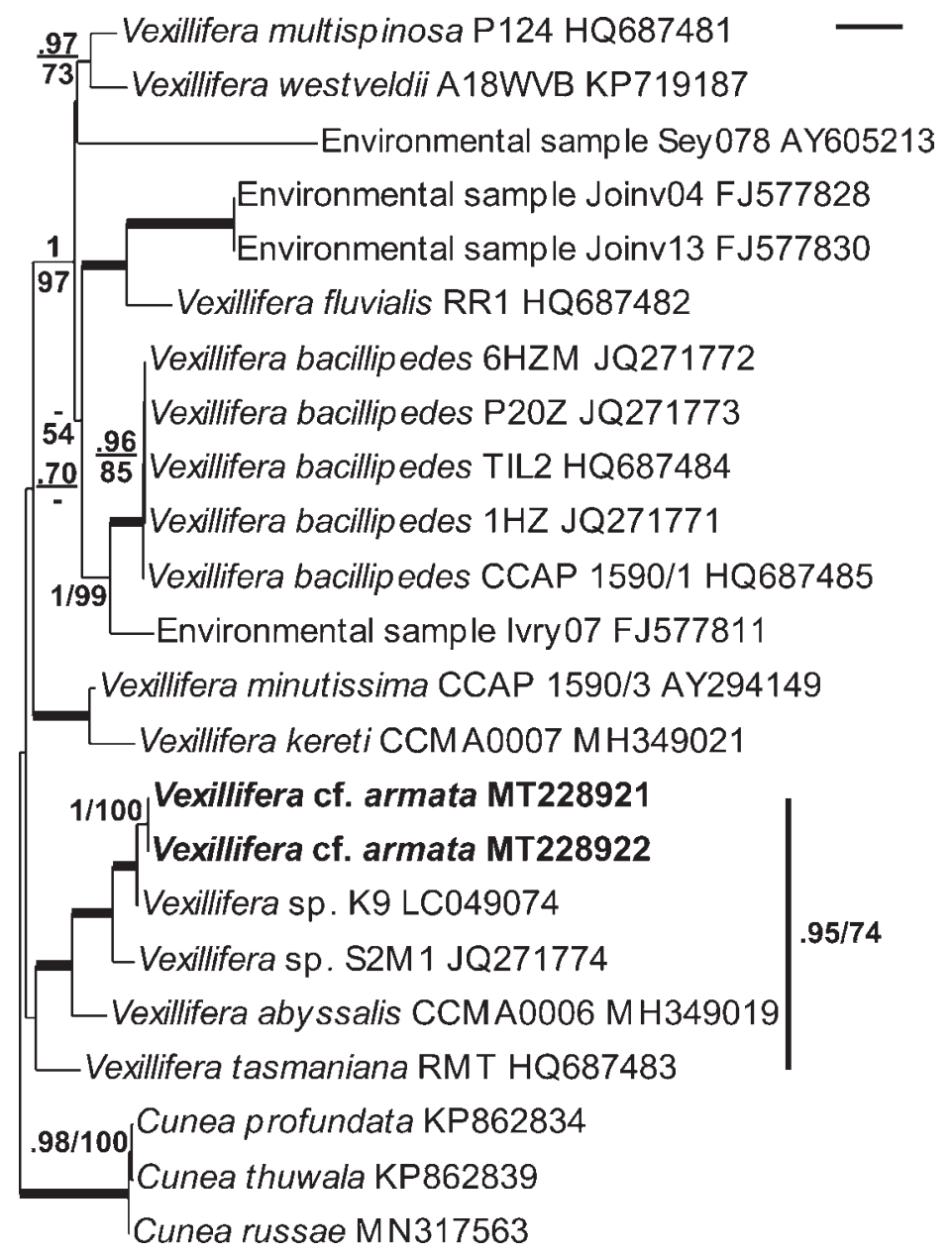

Fig. 5. Maximum likelihood phylogenetic tree of Vexillifera with Cunea spp. as outgroup. The tree is based on 23 SSU rRNA gene sequences (1450 unambiguously aligned nucleotide positions). New sequences of Vexillifera cf. armata are in bold. Numbers at nodes indicate Bayesian posterior probabilities/bootstrap values if above $0.5 / 50$. Thick lines $=1.0 / 100$. Scale bar -0.1 substitutions $/$ site.

Рис. 5. Филогенетическое древо представителей рода Vexillifera и представителей рода Cunеa в качестве внешней группы. Дерево построено по 23 последовательностям гена малой субъединицы рибосомной РНК (1450 надежно выровненных нуклеотидных позиций). Новые последовательности Vexillifera cf. armata обозначены жирным шрифтом. Числа показывают байесовские апостериорные вероятности/значения бутстрепа для соответствующих ветвей, если они превышают 0.5/50. Жирные линии соответствуют значениям 1.0/100. Масштабная черта соответствует 0,1 замене на нуклеотидную позицию.

Рис. 4. Филогенетическое древо Dactylopodida, построенное по алгоритму максимального правдоподобия, некоторые виды Vannellida использованы в качестве внешней группы. Дерево построено по 81 последовательности гена малой субъединицы рибосомной РНК (1516 надежно выровненных нуклеотидных позиций). Новые последовательности Vexillifera cf. armata обозначены жирным шрифтом. Числа показывают байесовские апостериорные вероятности/значения бутстрепа для соответствующих ветвей, если они превышают 0.5/50. Жирные линии соответствуют значениям $1.0 /$ 100. Косая линия между двумя кладами представителей рода Vexillifera означает, что в дереве, построенном в соответствии с байесовским алгоритмом, они поменялись местами. Масштабная черта соответствует 0,1 замене на нуклеотидную позицию. 


\section{Discussion}

Taxonomic affinity of the studied Vexillifera isolate

Based on the characters demonstrated by the light microscopic, ultrastructural and molecular investigation, the studied strain is assignable to the genus Vexillifera (Bovee, 1985; Kudryavtsev et al., 2018), and in particular looks very similar to Vexillifera armata Page, 1979. Amoebae of our strain and members of this species have an identical shape during locomotion, and similar floating forms. The glycocalyx of $V$. armata consists of prismatic hexagonal glycostyles that also have a similar size range to the glycostyles of the strain VO16.21I5.1 (Page, 1979a). In addition, amoebae share identical rod-like structures in the cytoplasm designated by Page (1979a) as "trichocyst-like bodies". However, there are several differences between the two amoebae that prevent us from a straightforward assignment of the strain VO16.21I5.1 to $V$. armata. Amoebae studied by Page were slightly smaller and "shorter" than those of VO16.21I5.1 (length 10-23 $\mu \mathrm{m}$ with the average $15.5 \mu \mathrm{m}$, length:breadth ratio $1-2.2$, average 1.6). Amoebae studied here had a broader range of length:breadth ratio, although it overlapped with that, measured by Page. The ranges of nuclear diameter also overlap, but the nuclei measured by Page were generally smaller. These morphological differences may be too small for assignment of our strain to a different morphospecies, but in addition, there are several indirect pieces of evidence that identification of the strain studied here as Vexillifera armata is uncertain. Unfortunately, no molecular data were obtained for the type strain of $V$. armata, and this strain was lost, therefore, we cannot perform a sequence comparison. However, there are unnamed strains of Vexillifera that have been recently studied using molecular data and belong to the same clade as the strain studied here. In this case morphological and molecular comparison can be performed. The strain which is most similar to VO16.21I5.1 was designated K9 without an assignment of a species name (Pizzetti et al., 2016). The sequenced part of its
SSU rRNA gene shows differences from the strain studied here in 6.1 and $6.3 \%$ of the nucleotide positions. Most of the differences are restricted to several local areas of the gene, in particular, there are clearly different nucleotide patterns in the helices $23 \mathrm{e} 12$ of the hypervariable region $\mathrm{V} 4,43 \mathrm{e}$ of the hypervariable region $\mathrm{V} 7,45 \mathrm{e}$ and $46 \mathrm{e}$ of the hypervariable region V8, and 49 of the hypervariable region V9. Unfortunately, no sequence data is available for the barcoding part of the V4 region of the SSU rRNA gene in the K9 strain. Morphologically this strain is similar to the one studied here, and $V$. armata. Size of its trophic cells varies within the similar range as that of $V$. armata (Table 1), but it had much higher length to breadth ratio. This strain also differed in the glycocalyx structure: its glycocalyx is described as amorphous, but its image shows an uneven fuzzy layer (Pizzetti et al., 2016). At least, it does not show any glycostyles. Vexillifera sp. strain K9 also demonstrated inclusions that were described as "wedge-shaped filamentous structures" without any fixed number or position in the cytoplasm (Pizzetti et al., 2016). These structures strongly resemble "trichocyst-like bodies" present in our strain and in $V$. armata Page, 1979, and may have the same nature. Vexillifera sp. K9 was also isolated from a marine habitat, a coastal lake on the Tyrrhenian coast of Italy with salinity 28.4-33.7\%o (Pizzetti et al., 2016), but there are no data on its salinity tolerance. The strain studied here was isolated from the Far Eastern benthic marine habitat with the salinity of $34 \%$, while $V$. armata, from Kingsbridge estuary (UK) where salinity was not measured during collection (Page, 1979), but comprises about 30\%o according to other records (http://apps. environment-agency.gov.uk/static/documents/nvz/ NVZ2017_ET8_Kingsbridge_Estuary_ Datasheet.pdf). The estuarine nature of this habitat suggests that its salinity may be variable.

In conclusion, there are three marine strains of Vexillifera with the significantly overlapping ranges of variation of their morphological characters. They all were isolated from marine habitats separated by long distances. Two most similar strains are $V$. armata Page, 1979 and 


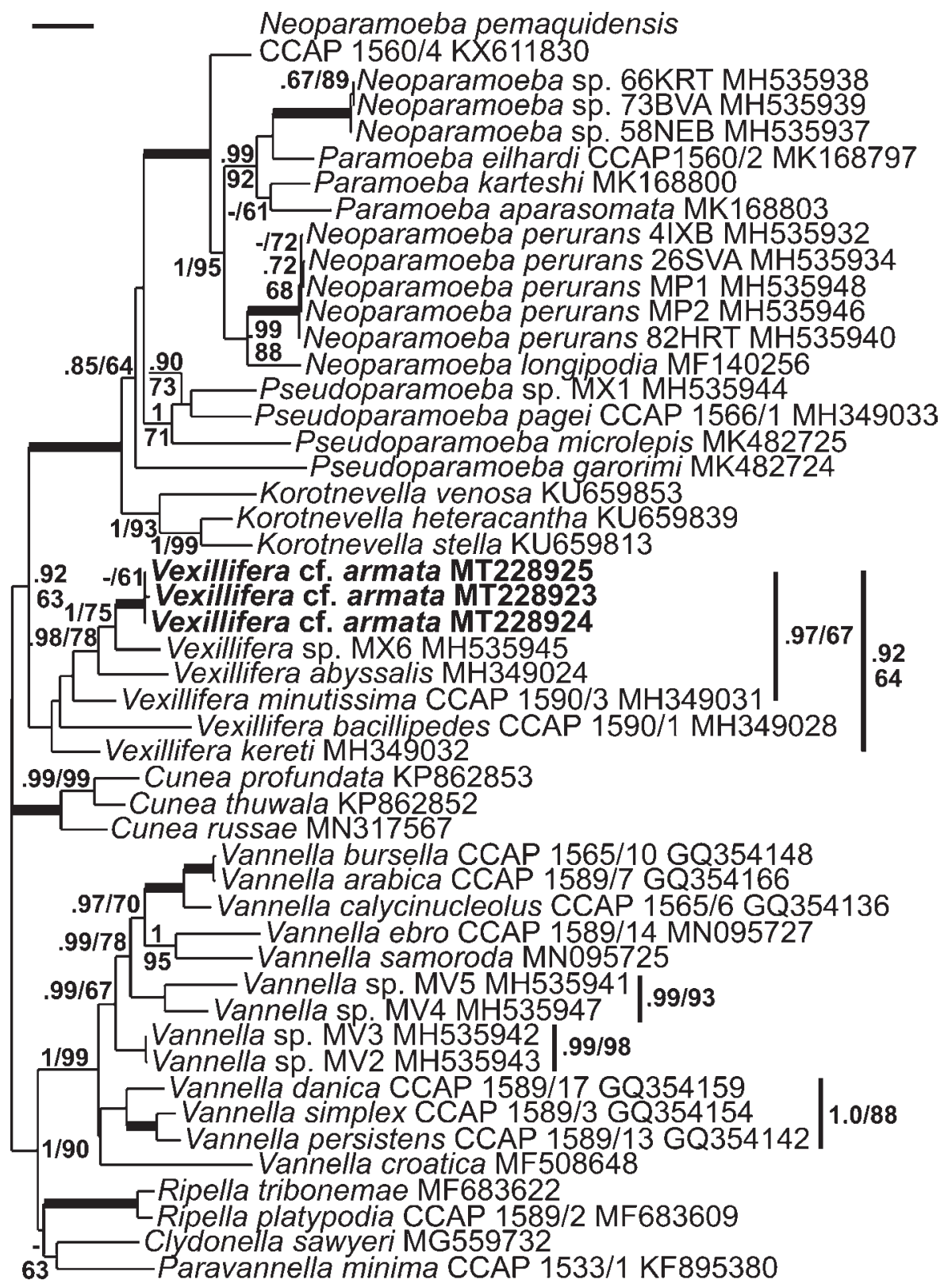

Fig. 6. Maximum likelihood phylogenetic tree of Dactylopodida with Vannellida as outgroup. The tree is based on 48 COI gene sequences (606 unambiguously aligned nucleotide positions). New sequences of Vexillifera cf. armata are in bold. Numbers at nodes indicate Bayesian posterior probabilities/bootstrap values if above $0.5 / 50$. Thick lines $=1.0 / 100$. Scale bar -0.1 substitutions $/$ site.

Рис. 6. Филогенетическое древо Dactylopodida, построенное по алгоритму максимального правдоподобия, Vannellida использованы в качестве внешней группы. Дерево построено по 48 последовательностям гена COI (606 надежно выровненных нуклеотидных позиций). Новые последовательности Vexillifera cf. armata обозначены жирным шрифтом. Числа показывают байесовские апостериорные вероятности/значения бутстрепа для соответствующих ветвей, если они превышают 0.5/50. Жирные линии соответствуют значениям 1.0/100. Масштабная черта соответствует 0,1 замене на нуклеотидную позицию. 
Table 1. Morphometric comparison of the strain VO16.21I.5.1, Vexillifera armata Page, 1979, and Vexillifera sp., strain K9 (Pizzetti et al., 2016).

Таблица 1. Сравнение морфометрических характеристик VO16.21I.5.1, Vexillifera armata Page, 1979 и Vexillifera sp., штамм K9 (Pizzetti et al., 2016)

\begin{tabular}{|l|l|l|l|}
\hline & VO16.21I.5.1 & $\begin{array}{l}\text { V.armata } \\
\text { Page, 1979 }\end{array}$ & $\begin{array}{l}\text { Vexillifera } \text { sp. } \\
\text { K9 }\end{array}$ \\
\hline $\begin{array}{l}\text { Locomotive form } \\
\text { size (length X } \\
\text { breadth, } \boldsymbol{\mu m})\end{array}$ & $\begin{array}{l}14.8-32.0 \text { X 7.4-19.3 } \\
\text { (average 20.5 X 12.1) }\end{array}$ & $\begin{array}{l}\text { Length 10-23 } \\
\text { (average 15.5) }\end{array}$ & $\begin{array}{l}\text { 10.1-21 X 4.4- } \\
13 \text { (average 14.8 } \\
\text { X 8.4) }\end{array}$ \\
\hline $\begin{array}{l}\text { Length:breadth } \\
\text { ratio }\end{array}$ & $\begin{array}{l}0.9: 1-2.9: 1 \text { (average } \\
1.8: 1)\end{array}$ & $\begin{array}{l}1.0: 1-2.2: 1 \\
\text { (average 1.6:1) }\end{array}$ & $\begin{array}{l}3.9: 1-9.5: 1 \\
\text { (average 5.9:1) }\end{array}$ \\
\hline $\begin{array}{l}\text { Nucleus X nucleolus } \\
(\boldsymbol{\mu m})\end{array}$ & $\begin{array}{l}3.3-5.7 \text { X 1.8-3.1 } \\
(\text { average 4.3 X 2.6) }\end{array}$ & $\begin{array}{l}2.8-4.2 \text { X 1.9- } \\
2.8\end{array}$ & Not provided \\
\hline & $\begin{array}{l}\text { Glycostyles: height } \\
\text { Glycocalyx, nm }\end{array}$ & $\begin{array}{l}\text { Glycostyles: } \\
\text { diameter 48.7-61.7 } \\
\text { height 60-70; } \\
\text { diameter 50 }\end{array}$ & $\begin{array}{l}\text { "Amorphous } \\
\text { glycocalyx", 10- } \\
\text { 20 nm thick }\end{array}$ \\
\hline
\end{tabular}

Vexillifera sp. VO16.21I5.1: their size ranges overlap, cell coat structure and ultrastructure of "trichocyst-like bodies" are almost identical. On the other hand, their habitats are geographically remote, and no molecular data are available for Page's strain. The extent of cryptic speciation has been getting more and more evident among the naked lobose amoebae recently (Kudryavtsev, Pawlowski, 2015; Tekle, Wood, 2018; Mesentsev, Smirnov, 2019; Kudryavtsev, Volkova, 2020; Lara et al., 2020; Mesentsev et al., 2020). For example, among the small dactylopodid amoebae that belong to the genus Cunea no sound morphological differences were found between three strains showing significant variation in their molecular sequences and ecological preferences (Kudryavtsev, Pawlowski, 2015; Kudryavtsev, Volkova, 2020). We have no reason to be confident that the same situation would not occur in the other genera of Amoebozoa, in particular, in Vexillifera. Therefore, a re-isolation of $V$. armata from its type location is highly desirable in order to perform molecular comparison with the strain studied here that until then has to be designated as Vexillifera cf. armata.

\section{Novel ultrastructural characteristics of Vexillifera}

A detailed comparison of the revealed glycocalyx structure of $V$. cf. armata VO16.21I5.1 with the original description of $V$. armata (Page, 1979) shows some structural differences that, if confirmed further, may clarify several aspects of this type of cell coat in Vexillifera. Page (1979a: 116) describes a basal layer of glycocalyx in $V$. armata that in cross-section looks like a line in ca. $12 \mathrm{~nm}$ above the plasma membrane. The hexagonal glycostyles are described as emerging from this basal layer. The results of our observation of $V$. cf. armata strain VO16.21I5.1 show clearly that the basal parts of the hexagonal glycostyles are separated from each other, and contrasting to the description of Page (1979a) there is no basal layer of glycocalyx that looks like a continuous line, but is rather made up of separate structures that serve as basal parts of each glycostyle (Fig. 3A). Under this interpretation, these glycostyles are rather attached to the plasma membrane surface in a way similar to the microscales. Interestingly, these structural features seem to look the same in some of the electron micrographs by Page (1979a), e.g., in his Fig. 12, however, his interpretation of these structures was different. Given the present data, we can question whether the glycocalyx structures of Vexillifera have the same structural characteristics as the glycostyles of Vannellida, i.e. whether they are truly embedded in the plasma membrane (Page, Blakey, 1979; Smirnov et al., 2007). It is prob- 
able, that the nature of their contact with the plasma membrane is similar to that of the microscales in scale-bearing dactylopodid amoebae, like species of the genera Paramoeba and Korotnevella. However, the question whether these structures are separable from the plasma membrane without destruction, which is the main criterion of the glycostyles, or not (Page, Blakey, 1979), remains open.

Electron-dense submembrane bodies (Fig. $3 \mathrm{~A}, \mathrm{~B}, \mathrm{D})$ are similar in size and structure to the collosome-like structures previously described among the dactylopodids in $V$. abyssalis and $V$. kereti (Kudryavtsev et al., 2018), and Cunea spp. (Kudryavtsev, Pawlowski, 2015; Kudryavtsev, Volkova, 2020). Initially, these structures were described by Page (1980) and Page and Willumsen (1983) in the members of the genera Rhizamoeba and Flabellula. The function of these structures has not yet been demonstrated.

\section{Molecular phylogeny of the genus Vexil- lifera}

The presented phylogenetic tree based on the SSU rRNA gene (Fig. 4) is to date the most complete for the genus Vexillifera, and shows several peculiar features. In particular, there are three stable clades of Vexillifera as shown previously (Kudryavtsev et al., 2018) that differ in their origin. Two basal clades are from brackish water/marine habitats, and one derived clade comprises freshwater species. Interestingly, a discrepancy was observed between ML and Bayesian phylogenetic trees with respect to the the position of the two marine branches of Vexillifera that were swapped in these trees (Fig. 4), and their position was poorly supported. This artifact can probably be explained by the high evolutionary rates in the clade of Vexillifera spp. and the fact that presumably vexilliferan environmental sequences were included for the first time in the current phylogenetic analyses. These could have a destabilizing effect on the tree topology, as some of these sequences are also incomplete. This effect could be overcome by the reduction of the number of outgroup sequences (Fig. 5). When the dataset was reduced to only Vexillifera spp. with Cunea spp. added as outgroup, the position of the two clades stabilized against the algorithm of analysis, but still was poorly supported with bootstrap/ Bayesian posterior probability. Anyway, all three clades are fairly well-supported, and based on these reconstructions, a scenario suggesting a single evolutionary transition between marine and freshwater biotopes seems to be reasonable.

A similar tree topology is not reproduced by the COI gene analysis (Fig. 6). This situation was noticed before (Kudryavtsev et al., 2018), and it can be explained by the short length of the COI sequences and their high evolutionary rates combined with a small number of sequenced species. Therefore, COI gene may not be a suitable marker for reconstruction of the evolutionary relationships between species of Vexillifera, but it can be used to determine the species identity.

Analysis of the SSU rRNA gene sequences shows that the clade corresponding to the genus Vexillifera comprises, besides named species, four sequences of the uncultured amoebozoans. These are Ivry07 (FJ577811) that branches as sister to $V$. bacillipedes, Joinv04 and Joinv13 (FJ577828 and FJ577830, respectively), sisters to V.fluvialis, and Sey078 (AY605213) that occupies the most basal position in the clade of freshwater Vexillifera spp. The former three sequences originate from the study of microbial communities of the water treatment plants in France (Poitellon et al., 2009), while the latter, from the Seymaz River in Switzerland (Berney et al., 2004). Although these sequences are quite divergent from those of the named species and form long branches in the tree, they share several nucleotide patterns in the conserved sites, typical of the other species of Vexillifera that is additional evidence that these sequences belong to the genuine members of this genus.

Our data indicate that members of the revealed Vexillifera clades demonstrate different morphological characters that make it difficult to outline morphological boundaries between these clades. This problem was also faced by Kudryavtsev et al. (2018), however, with accumulation of the amount of investigated species evolutionary trends in morphology may become 
evident. We can currently mention that the possible common feature of the freshwater species of Vexillifera is the presence of refractile inclusions in the cytoplasm (Bovee, 1985; Mascaro et al., 1985; Page, 1988; Dyková et al., 2011; Van Wichelen et al., 2016). One of the marine branches $(V$. minutissima $+V$. kereti) shares nucleus with peripheral nucleoli (Page, 1983; Kudryavtsev et al., 2018). The cell coat structure is variable among branches, but we can mention that generally, it is either an uneven amorphous layer, or it consists of separate distinct units first described as "T-shaped glycostyles" (Mascaro et al., 1985) in the species of freshwater origin (Page, 1979b, 1988; Dyková et al., 2011). It is the same in the species of marine origin (Dyková et al., 2011; Pizzetti et al., 2016; Kudryavtsev et al., 2018), or they may possess hexagonal glycostyles. Interestingly, the latter are recorded in two independent evolutionary branches: $V$. minutissima $+V$. kereti (in $V$. minutissima), and in a branch probably related to $V$. armata (in $V$. armata Page, 1979a and $V$. cf. armata strain VO16.21I.5.1) (Page, 1979a, 1983). The cell coat consisting of "Tshaped structures" also occurs in the other clades of the Dactylopodida, in particular, in Cunea spp. (Kudryavtsev, Pawlowski, 2015; Kudryavtsev, Volkova, 2020). Based on this data, we can suggest that this type of a cell coat structure is probably basal for Vexillifera, while hexagonal glycostyles may have evolved several times independently in different clades. This is similar to the hypothesis of the evolution of pentagonal glycostyles in the order Vannellida (Smirnov et al., 2007).

\section{Marine species of Vexillifera and their relations to environmental salinity.}

Few attempts to determine ranges of salinity tolerance in marine members of the genus Vexillifera have been made before. In particular, Schaeffer (1926) reported that Vexillifera aurea did not tolerate the seawater dilution below $25 \%$ (i.e. ca. $8 \%$ ), but did not show any significant changes in $50 \%$ dilution (15-16\%). Sawyer (1975) investigated the subject in two other species of Vexillifera - V. browni and V. ottoi isolated from the Chincoteague Bay (Atlantic coast, USA). He found that these species neither survived nor grew at salinities of $15 \%$ and below. Unfortunately, no experimental data on salinity tolerance were collected for $V$. armata or Vexillifera sp. K9 (Pizzetti et al., 2016). However, the data we obtained during this study indicate a relative stenohalinity of strain Vexillifera $\mathrm{cf}$. armata described here: the growth and survival of the studied strain could only be maintained at salinity values of $15-50 \%$, and no further dilution or increase in the salinity was tolerated. This remarkable feature is in accordance with the conditions in the original biotope where the strain was isolated: sublittoral benthos of the Sea of Japan, at the depth of $70 \mathrm{~m}$. Probably, no significant salinity oscillations in this biotope occur, therefore, the studied amoeba is not adapted to the higher and lower salinity values. It remains open, however, whether this strain can tolerate a broader range of salinities once exposed to the marginal values for a prolonged period of time.

\section{List of data and materials derived from this study}

The type material designated for $V$. armata Page, 1979 is stored at the Natural History Museum (London, UK) as a series of permanent slides (Page, 1979). The strain Vexillifera $\mathrm{cf}$. armata VO16.21I.5.1 is preserved in the form of a culture (accession No RC CCMAm 0466), Epon embedding for transmission electron microscopy (accession No F140) and two purified samples of the total genomic DNA (accession Nos A566, A571), maintained at the resource center "Culture Collection of Microorganisms" of the St. Petersburg State University Research Park, Russia. Accession numbers for the molecular sequence data are: MT228921-MT228922 (SSU rRNA gene), MT228923-MT228925 (COI gene). Video record of living amoebae is publicly available at: https://youtu.be/ ErsePXUikCo.

Acknowledgements. We dedicate this publication to the memory of the late Andrey Alexandrovich Dobrovolskij, a gentle, reliable and 
supportive teacher to all of us who passed away last year. The authors are grateful to Prof. A.V. Chernyshov, Prof. V.V. Yushin (Laboratory of Embryology, National Scientific Center of Marine Biology, Far-Eastern Branch of RAS) for the possibility to use laboratory rooms at the Vostok marine station of the NSCMB; staff of the Vostok station, in particular, Nikolay Kashenko for help with sampling and initial processing of the material. Supported by the ZIN RAS budgetary grant AAAA-A19-119031200042-9 to AK and RFBR grant 18-34-00726-mol-a to EV (electron microscopic study and salinity tolerance investigations).

\section{Compliance with ethical standards}

Conflict of Interest: The authors declare that they have no conflict of interest.

Ethical approval: This article does not contain any studies with animals performed by any of the authors.

\section{Supporting Information}

Additional Supporting Information may be found online:

Supplementary video S1. Living amoebae on the glass surface.

\section{References}

Berney C., Fahrni J., Pawlowski J. 2004. How many novel eukaryotic "kingdoms"? Pitfalls and limitations of environmental DNA surveys // BMC Biology. Vol.2. No.13.

Bovee E.C. 1985. The lobose amebas III. Descriptions of nine new conopodous amebas of the genus Vexillifera Schaeffer, 1926, emd. Bovee 1951, 1970, with comments on the genus // Arch. Protistenkd. Vol.129. No.1-4. P.101-118.

Bovee E.C., Sawyer T.K. 1979. Marine flora and fauna of the northeastern United States. Protozoa: Sarcodina: Amoebae. NOAA Technical Report NMFS Circular 419. Seattle, Wash.: National Marine Fisheries Service. $56 \mathrm{p}$.

Dyková I., Kostka M. 2013. Illustrated guide to culture collection of free-living amoebae. Praha: Academia. $363 \mathrm{p}$.

Dyková I., Kostka M., Pecková H. 2011. Three new species of the amoebozoan genus Vexillifera Schaeffer, 1926 // Acta Protozool. Vol.50. No.1. P.55-63.

English C.J., Tyml T., Botwright N.A., Barnes A.C., Wynne J.W., Lima P.C., Cook M.T. 2019. A diversity of amoebae colonise the gills of farmed Atlantic salmon (Salmo salar) with amoebic gill disease (AGD) // Eur. J. Protistol. Vol.67. P.27-45.

Kudryavtsev A., Pawlowski J. 2015. Cunea n. g. (Amoebozoa, Dactylopodida) with two cryptic species isolated from different areas of the ocean // Eur. J. Protistol. Vol.51. No.3. P.197-209.

Kudryavtsev A., Pawlowski J., Hausmann K. 2009. Description and phylogenetic relationships of Spumochlamys perforata $\mathrm{n}$. sp. and Spumochlamys bryora $\mathrm{n}$. sp. (Amoebozoa, Arcellinida) // J. Eukaryot. Microbiol. Vol.56. No6. P.495-503.

Kudryavtsev A., Pawlowski J., Smirnov A. 2018. More amoebae from the deep-sea: Two new marine species of Vexillifera (Amoebozoa, Dactylopodida) with notes on taxonomy of the genus // Eur. J. Protistol. Vol.66. P.9-25.

Kudryavtsev A., Volkova E. 2020. Cunea russae n. sp. (Amoebozoa, Dactylopodida), another cryptic species of Cunea Kudryavtsev and Pawlowski, 2015, inhabits a continental brackish-water biotope // Eur. J. Protistol. Vol.73. No.125685.

Kudryavtsev A., Volkova E., Plotnikov A. 2019. Vannella samoroda n. sp. (Amoebozoa) - first member of the genus from a continental saline habitat placed in a molecular tree // Eur. J. Protistol. Vol.71. No.125634.

Lara E., Dumack K., García-Martín J.M., Kudryavtsev A., Kosakyan A. 2020. Amoeboid protist systematics: A report on the "Systematics of amoeboid protists" symposium at the VIIIth ECOP/ISOP meeting in Rome, 2019 // Eur. J. Protistol. Vol.76. No.125727.

Maniatis T., Fritsch E.F., Sambrook J. 1982. Molecular cloning, a laboratory manual. New York: Cold Spring Harbor Laboratory. 545 p.

Mascaro M.L., Osuna A., Mascaro C. 1985. Vexillifera granatensis n. sp. (Gymnamoebia, Paramoebidae), a new amoeba from fresh water// Protistologica. Vol.21. No.4. P.467-471.

Medlin L., Elwood H.J., Stickel S., Sogin M.L. 1988. The characterization of enzymatically amplified eukaryotic 16S-like rRNA coding regions. Gene. Vol.71. No.2. P.491-499.

Mesentsev Y.S., Smirnov A.V. 2019. Thecamoeba cosmophorea $\mathrm{n}$. sp. (Amoebozoa, Discosea, Thecamoebida) - An example of sibling species within the genus Thecamoeba // Eur. J. Protistol. Vol.67. P.132-141.

Mesentsev Y.S., Kamyshatskaya O.G., Smirnov A.V. 2020. Thecamoeba foliovenanda $\mathrm{n}$. sp. (Amoebozoa, Discosea, Thecamoebida) - One more case of sibling species among amoebae of the genus Thecamoeba // Eur. J. Protistol. Vol.76. No.125716.

Mullen T.E., Nevis K.R., O’Kelly C.J., Gast R.J., Frasca J.S. 2005. Nuclear small-subunit ribosomal RNA genebased characterization, molecular phylogeny and PCR detection of the Neoparamoeba from western long island sound lobster // J. Shellfish Res. Vol.24. No.3. P.719-731.

Nassonova E., Smirnov A., Fahrni J., Pawlowski J. 2010. Barcoding amoebae: comparison of SSU, ITS and COI genes as tools for molecular identification of naked lobose amoebae // Protist. Vol.161. No.1.P.102- 
115.

Page F.C. 1969. Mitosis and pseudopod formation in Vexillifera bacillipedes n. sp., a mayorellid amoeba // Trans. Am. Microsc. Soc. Vol.88. No.3. P.394-400.

Page F.C. 1972. A study of two Mayorella species and proposed union of the families Mayorellidae and Paramoebidae (Rhizopodea, Amoebida) // Arch. Protistenkd. Vol.114. No.2. P.404-420.

Page F.C. 1979a. Vexillifera armata n. sp. (Gymnamoebia, Paramoebidae), an estuarine amoeba with distinctive surface structures and trichocyst-like bodies // Protistologica. Vol.15. No.1. P.111-122.

Page F.C. 1979b. The fine structure of Vexillifera bacillipedes (Amoebida, Paramoebidae) // Arch. Protistenkd. Vol.122. No.1-2. P.9-19.

Page F.C. 1980. A light- and electron-microscopical comparison of limax and flabellate marine amoebae belonging to four genera // Protistologica Vol.16. No.1. P.57-78.

Page F.C. 1983. Marine gymnamoebae. Cambridge, England: Institute of Terrestrial Ecology, Culture Centre of Algae and Protozoa. 54 p.

Page F.C. 1988. A new key to freshwater and soil gymnamoebae. Ambleside: Freshwater Biological Association. 122 p.

Page F.C., Blakey S.M. 1979. Cell surface structure as a taxonomic character in the Thecamoebidae (Protozoa: Gymnamoebia) // Zool. J. Linn. Soc. Vol.66. No.2. P.113-135.

Page F.C., Willumsen N.B.S. 1983. A light- and electronmicroscopical study of Para?abellula reniformis (Schmoller, 1964), type species of a genus of amoebae (Amoebida, Flabellulidae) with subpseudopodia // Protistologica Vol.19. No.4. P.567-575.

Peglar M.T., Amaral Zettler L.A., Anderson O.R., Nerad T.A., Gillevet P.M., Mullen T.E., Sogin M.L. 2003. Two new small?subunit ribosomal RNA gene lineages within the subclass Gymnamoebia // J. Eukaryot. Microbiol. Vol.50. No.3. P.224-232.

Penard E. 1890. Über einige neue oder wenig bekannte Protozoën // Jahrb. Nassau. Ver. Naturkd. Bd.43. S.73-91.

Penard E. 1902. Faune rhizopodique du bassin du Léman. Geneva: Henry Kündig, Libraire de l'Institut. 714 p.

Pizzetti I., Schulz F., Tyml T., Fuchs B.M., Amann R., Horn M., Fazi S. 2016. Chlamydial seasonal dynamics and isolation of 'Candidatus Neptunochlamydia vexilliferae' from a Tyrrhenian coastal lake // Env. Microbiol. Vol.18. No.8. P.2405-2417.

Poitelon J.-B., Joyeux M., Welte B., Duguet J.-P., Peplies J., DuBow M.S. 2009. Identification and phylogeny of eukaryotic 18S rDNA phylotypes detected in chlori- nated finished drinking water samples from three Parisian surface water treatment plants // Lett. Applied Microbiol. Vol.49. No.5. P.589-595.

Rambaut A., Suchard M.A., Xie D., Drummond A.J. 2014. Tracerv1.6. Available from: http://beast.bio. ed.ac.uk/ Tracer.

Ronquist F., Teslenko M., Van Der Mark P., Ayres D.L., Darling A., Höhna S., Huelsenbeck J.P. 2012. MrBayes 3.2: efficient Bayesian phylogenetic inference and model choice across a large model space // Syst. Biol. Vol.61. No.3. P.539-542.

Sawyer T.K. 1975. Marine amoebae from surface waters of Chincoteague Bay, Virginia: two new genera and nine new species within the families Mayorellidae, Flabellulidae, and Stereomyxidae // Trans. Amer. Micros. Soc. Vol.94. No.1. P.71-92.

Schaeffer A.A. 1926. Taxonomy of the amebas with descriptions of thirty-nine new marine and freshwater species // Papers from the department of Marine Biology of the Carnegie Institute of Washington. Vol.24. Washington: The Carnegie Institute of Washington. $116 \mathrm{p}$.

Smirnov A., Nassonova E., Berney C., Fahrni J., Bolivar I., Pawlowski J. 2005. Molecular phylogeny and classification of the lobose amoebae // Protist. Vol.156. No.2. P.129-142.

Smirnov A.V., Brown S. 2004. Guide to the methods of study and identification of soil gymnamoebae // Protistology. Vol.3. No.3. P.148-190.

Smirnov A.V., Nassonova E.S., Chao E., Cavalier-Smith T. 2007. Phylogeny, evolution, and taxonomy of vannellid amoebae // Protist. Vol.158. No.3. P.295-324.

Stamatakis A. 2014. RAxML version 8: a tool for phylogenetic analysis and post-analysis of large phylogenies // Bioinformatics. Vol.30. No.9. P.1312-1313.

Tekle Y.I., Wood F.C. 2018. A practical implementation of large transcriptomic data analysis to resolve cryptic species diversity problems in microbial eukaryotes // BMC Evol. Biol. Vol.18. No.170.

Van Wichelen J., D'Hondt S., Claeys M., Vyverman W., Berney C., Bass D., Vanormelingen P. 2016. A hotspot of amoebae diversity: 8 new naked amoebae associated with the planktonic bloom-forming cyanobacterium Microcystis // Acta Protozool. Vol.55. No.2. P.6187.

Wailes G.H. 1932. Description of new species of protozoa from British Columbia // Contrib. Can. Biol. Fish. Vol.7. No.1. P.213-219.

Wong F.Y.K., Carson J., Elliott N.G. 2004. 18S ribosomal DNA-based PCR identification of Neoparamoeba pemaquidensis, the agent of amoebic gill disease in sea-farmed salmonids // Dis. Aquat. Org. Vol.60. No.1. P.65-76.

Responsible editor V.V. Aleshin 